\begin{tabular}{|l|l|l||}
\hline \multicolumn{2}{|c|}{ PublisherInfo } \\
\hline \hline PublisherName & $:$ & BioMed Central \\
\hline \hline PublisherLocation & $:$ & London \\
\hline \hline PublisherImprintName & $:$ & BioMed Central \\
\hline \hline
\end{tabular}

\title{
Anaesthetics and hypothermia reduce damge to neuronal cells following cerebral ischaemia
}

\begin{tabular}{||l|l|l||}
\hline \multicolumn{2}{|c||}{ ArticleInfo } \\
\hline \hline ArticleID & $:$ & 4258 \\
\hline \hline ArticleDOI & $:$ & $10.1186 /$ ccf-2000-6600 \\
\hline \hline ArticleCitationID & $:$ & 6600 \\
\hline \hline ArticleSequenceNumber & $:$ & 46 \\
\hline \hline ArticleCategory & $:$ & Paper Report \\
\hline ArticleFirstPage & $:$ & 1 \\
\hline \hline ArticleLastPage & $:$ & 3 \\
\hline \hline & $:$ & RegistrationDate : 2000-10-12 \\
ArticleHistory & $:$ & OnlineDate \\
\hline \hline ArticleCopyright & $:$ & Current Science Ltd2000-10-12 \\
\hline \hline ArticleGrants & $:$ & \\
\hline \hline ArticleContext & $:$ & 1305433 \\
\hline \hline
\end{tabular}


Aff1 Southampton General Hosptal, UK

\section{Keywords}

Cerebral ischemia, cerebral protection, hypothermia, inhaled anesthetics

\section{Comments}

This is an interesting in vitrostudy, the findings of which support the evidence that neuroprotection afforded by anaesthetic agents is a specific feature of the agent. It seems increasingly likely that burst suppression or reduction in metabolic rate is not the end of the story. Therapeutic concentrations of both isoflurane and thiopentone had similar effectiveness in increasing the proportion of undamaged neuronal cells following anoxia from $70 \%$ to in excess of $90 \%$. Further tests showed that glutamate-induced neuronal damage was prevented by isoflurane. This inhibition most probably occurs at the N-methyl-Daspartate (NMDA) receptor. This study provides another strand of evidence that may bring about a better understanding of why anaesthetic agents are neuroprotective and thus lead to improved strategies for neurosurgical procedures. What needs to be investigated is whether use of thiopentone or isoflurane shortly after the anoxic insult can attenuate cell death. This would then have implications for the prevention of secondary injury for head injured patients.

\section{Introduction}

Intravenous and inhaled anaesthetic agents have been shown to have neuroprotective actions. Volatile agents reduce glutamate receptor mediated calcium influx, ischaemia-induced glutamate release, and the activity of NMDA-type glutamate receptors. These actions have not been fully investigated and the relative protection afforded by hypothermia, isoflurane or thiopentone has not been examined. This study uses hippocampal slices rather than cultured cells and looks directly for both cell damage and cell death which gives it increased validity. Other papers on the subject have looked at raised intracellular calcium or recovery of neurotransmission as surrogates of cell damage.

\section{Methods}


. A contolled in vitro study using rat hippocampal slices

. Slices were subjected to a 10 or $20 \mathrm{~min}$ period of anoxia followed by a $5 \mathrm{~h}$ recovery period

. Slices were exposed to one of several different treatments. These included altering the temperature of the artificial cerebrospinal fluid (aCSF) bathing the slices $\left(34^{\circ} \mathrm{C}, 37^{\circ} \mathrm{C}, 40^{\circ} \mathrm{C}\right)$, or adding either sodium thiopentone $(50 \mu \mathrm{M})$, isoflurane $(0.7 \%$ or $2 \%)$, or MK801 (an NMDA receptor blocking agent) to the aCSF bath. A sham group with/without anoxia was also included

. A further subgroup of slices were bathed in either glutamate alone, glutamate with MK801 or glutamate with isoflurane

. Following recovery, the slices were fixed and examined microscopically

. The percentage of dead or damaged cells within a fixed area was then examined

\section{Results}

There were differences in the level of neuronal damage within different neuron subgroups. CA1 neurons showed the most sensitivity to damage and hence these cells were studied to assess treatment outcome.Mild hypothermia $\left(34^{\circ} \mathrm{C}\right)$ reduced damage in all three groups, whereas hyperthermia caused an increase in damage.Swelling and death of CA1 neurons was completely prevented by MK801.Isoflurane at $0.7 \%, 2 \%$ or thiopentone both reduced cell death and cell damage to a similar degree. Glutamateinduced cell death was prevented by both MK801 and isoflurane.

\section{References}

1. Popovic R, Liniger R, Liniger R : Anesthetics and mild hypothermia similarly prevent hippocampal neuron death in an in vitromodel of cerebral ischemia. Anesthesiology. 2000, 92: 1343-1349. 